Avoimesti luettavissa osoitteessa http://journal.fi/ainedidaktiikka

ainedidaktiikka

\title{
Biologian ja maantieteen opetuksessa käytettävät ilmastonmuutoksen opetusmenetelmät
}

\author{
Eija Yli-Panula ${ }^{1}$, Eila Jeronen ${ }^{2}$, Salla Koskinen ${ }^{3}$ ja Sofia Vesterkvist ${ }^{3}$ \\ ${ }^{1}$ Kasvatustieteiden tiedekunta, Turun yliopisto \\ ${ }^{2}$ Kasvatustieteiden tiedekunta, Oulun yliopisto \\ ${ }^{3}$ Luonnontieteiden ja tekniikan tiedekunta, Turun yliopisto
}

\begin{abstract}
$\mathbf{y}$
Tässä kvalitatiivisessa tutkimuksessa selvitettiin biologian ja maantieteen opetuksessa käytettyjä ilmastonmuntosta koskevia opetusmenetelmiä ja niiden tukemista tiedon ja ajattelun tasoista. Tutkimuskysymyksiksi muodostuivat: 1) Mitä ilmastonmuutoksen oppimista edistäviä opetusmenetelmiä biologiassa ja maantieteessä käytetään? 2) Millaisia oppilaiden tiedon ja ajattelun tasoja ilmastonmuutoksen opetuksessa käytetyt opetusmenetelmät tukevat? Tutkimukseen valikoitui 14 kansainvälistä tieteellistä artikkelia $(N=159)$. Valinnan kriteereinä olivat: oppisisältö, julkaisuvuodet 2000-2019 sekä kohderyhminä peruskoululaiset ja lukiolaiset. Lisäksi artikkelissa tuli olla ainakin yksi opetusmenetelmä. Opetusmenetelmät tutkittiin aineistolähtöisellä sisällönanalyysillä. Opetusmenetelmien tukemia tiedon ja ajattelun tasoja analysoitiin teoriaohjaavalla sisällönanalyysillä. Sekä biologiassa että maantieteessä yleisimpiä opetusmenetelmiä olivat tutkiva oppiminen, ongelmanratkaisu, ryhmätyöt ja opettajakeskeiset opetusmenetelmät. Maantieteessä käytettiin biologiaa monipuolisemmin erilaisia ilmastonmuutoksen opiskelua edistäviä opetusmenetelmiä. Opetusmenetelmät tukivat korkeampia tiedon ja ajattelun tasoja harvemmin kuin alempia. Osa käytetyistä opetusmenetelmistä mahdollistaa omien kokemusten jakamisen ja päättelyn ryhmässä, mikä tukee opiskelijoiden oman ajattelun ymmärtämistä ja kriittistä ajattelua.
\end{abstract}

Ajattelun tasot, ilmastonmuutos, opetusmenetelmät, tiedon tasot

Lähetetty: 4.4.2020

Hyväksytty: 22.10.2020

Vastuukirjoittaja: eija.yli-panula@utu.fi

DOI: $10.23988 / \mathrm{ad} .98284$ 


\section{Johdanto}

Ilmastonmuutos on laajalti hyväksytty vakavaksi ihmiskuntaa uhkaavaksi ympäristöongelmaksi. Ilmastonmuutoksen uhkia koskeva lisääntynyt tieto, ilmiöstä tiedottaminen ja sen käsittely ovat aiheuttaneet nuorilla voimattomuuden tunnetta ja jopa ympäristöahdistusta (Macy, 1995; Norgaard, 2011; Pihkala, 2019; Stoknes, 2015). Ihmisen haitallisia ympäristövaikutuksia voidaan kuitenkin vähentää ja mahdollisesti jopa estää koulutuksen avulla (Dufty, 2018). Kiinnostus ilmastonmuutoksen opetukseen onkin lisääntynyt viime vuosina (Anderson, 2012).

Ilmastonmuutoksen opetus on haastavaa (Cantell, Tolppanen, Aarnio-Linnavuori \& Lehtonen, 2019). Siihen on useita syitä. Ensiksi ilmastonmuutos ilmiönä on monimutkainen asia opettaa, sillä sen seuraukset näkyvät sekä maapallonlaajuisena lämpenemisenä että alueellisina lämpötilan, sateisuuden ja tuulisuuden muutoksina sekä valtameren pinnan nousuna. Toiseksi ilmastonmuutoksen opetus ei ole käsitteenä vakiintunut, vaan siitä puhutaan esimerkiksi ilmastokasvatuksena, ilmastonmuutosopetuksena ja ilmastonmuutokseen liittyvänä opetuksena, minkä seurauksena sen päämäärää ja tavoitteita voi olla vaikea hahmottaa, vaikka ne olisivat samojakin (vrt. Lehtonen \& Cantell, 2015). Kolmanneksi lisääntynyt didaktinen tieto ei ole tarjonnut ratkaisua siihen, millaista ilmastonmuutoksen opetuksen tulisi olla (Tolppanen, Aarnio-Linnanvuori, Cantell \& Lehtonen, 2017).

Tässä tutkimuksessa ilmastonmuutoksen opetus ymmärretään Andersonin (2012) tavoin ympäristökasvatuksen ja kestävän kehityksen kasvatuksen osa-alueena, jonka ydinkäsite on ilmastonmuutoksen lukutaito. Andersonin (2012) määritelmän mukaan ilmastonmuutoksen lukutaito tarkoittaa, että opiskelijat ymmärtävät ilmastonmuutokseen liittyviä luonnontieteellisiä käsitteitä ja niiden välisiä suhteita sekä ilmastonmuutoksen ja oman toimintansa vaikutuksia ympäristöön. Ilmastonmuutoksen opetus on moni- ja poikkitieteistä ja sisältää ilmastonmuutosta koskevien tietojen lisäksi ympäristöllisiä ja sosiaalisia aiheita sekä saasteiden vähentämiseen ja kestävään kulutukseen ja elintapaan liittyviä asioita (Anderson, 2012). Ilmastonmuutoksen opetus on haasteellista esimerkiksi sen vuoksi, että ilmastonmuutosta koskeviin oppisisältöihin liittyy paljon virhekäsityksiä (Chen, 2011; Choi, Niyogi, Shepardson \& Charusombat, 2010; Monroe, Hall \& Li, 2017; Ratinen, 2016; Sterman, 2011). Monilta nuorilta puuttuvat perustiedot ja ymmärrys ilmastonmuutoksesta (Leiserowitz, Smith \& Marlon, 2011; Shepardson, Niyogi, Choi \& Charusombat, 2009; Taber \& Taylor 2009). Kun opetus perustuu integroituun, moni- ja poikkitieteiseen opetussuunnitelmaan, ilmastonmuutoksen lukutaitoa voidaan kehittää oppilaskeskeisten aktiivisten opetusmenetelmien avulla (Anderson, 2012).

Suomalaisissa perusopetuksen ja lukion opetussuunnitelmien perusteissa painotetaan oppiainerajat ylittävää yhteistyötä sekä suositellaan oppilaskeskeisiä aktiivisia opetusmenetelmiä (Tolppanen ym., 2017). Ilmastonmuutos ja sen ekologiset vaikutukset on mainittu yleisellä tasolla 
(Open ilmasto-opas, 2019a; Opetushallitus, 2014; 2015; 2019). Oppiainekohtaisesti ilmastonmuutoksen opetusta sisältyy lähinnä vain perusopetuksen biologian, maantiedon ja ympäristöopin tavoitteisiin ja sisältöihin sekä lukion biologian ja maantieteen tavoitteisiin ja sisältöihin sekä kestävän kehityksen ja globaalin vastuun aihekokonaisuuteen (Opetushallitus, 2014; 2015; 2019). Biologian opetussuunnitelmien sisällöissä neuvotaan tarkastelemaan, miten muuttuva ilmasto vaikuttaa elämään maapallolla ja tukemaan ilmiöiden syvällistä ymmärtämistä (Opetushallitus, 2014; 2015; 2019). Lisäksi biologiassa opetetaan ja harjoitutetaan oppilaiden ilmastonmuutokseen vaikuttamistaitoja ja ilmastoystävällisen maailman rakentamista (Opetushallitus, 2014; 2015; 2019). Maantieteen ytimessä ilmastonmuutoksen opetus on maantieteen kokonaisvaltaisen, maapalloisen ja alueellisen luonteen vuoksi (Opetushallitus, 2014; 2015; 2019). Luonnontieteiden ja yhteiskuntatieteiden välimaastossa olevana oppiaineena maantiede tukee muun muassa ilmastokysymysten ymmärtämistä ja ongelmien ratkaisemista esimerkiksi paikkatiedon apuvälineiden käytön sekä yhdyskuntasuunnittelun opetuksen kautta.

Ilmastonmuutoksen opetusta koskevia artikkeleita on julkaistu runsaasti, mutta yhtenäistä näkemystä ei edelleenkään ole siitä, millaisia strategioita ilmastonmuutoksen opetuksessa tulisi käyttää (Monroe ym., 2017). Eräs opetusstrategian osa ovat opetusmenetelmät. Artikkelissa niitä tarkastellaan perusopetuksen biologian ja maantiedon (tässä artikkelissa eteenpäin maantiede) sekä lukion maantieteen osalta tavoitteena antaa kuvaa käytetyistä opetusmenetelmistä ja siitä, mitä tiedon ja ajattelun tasoja niillä voidaan tukea.

Tutkimus perustuu kahteen tutkimuskysymykseen: 1) Mitä ilmastonmuutoksen oppimista edistäviä opetusmenetelmiä biologiassa ja maantieteessä käytetään? ja 2) Millaisia oppilaiden tiedon ja ajattelun tasoja ilmastonmuutoksen opetuksessa käytetyt opetusmenetelmät tukevat?

Tutkimuskysymykset taustoitetaan käsittelemällä ensin lyhyesti ilmastonmuutoksen opetusta ja siihen liittyviä ongelmia. Sen jälkeen kuvataan opetusmenetelmiä, joilla ongelmia on pyritty ratkaisemaan. Lopuksi tarkastellaan tiedon ja ajattelun tasoja mukautettuina ilmastonmuutoksen opetukseen biologiassa ja maantieteessä.

\section{Teoreettinen viitekehys}

\section{Ilmastonmuutoksen opetus ja opetusmenetelmät}

Ilmastonmuutoksella tarkoitetaan globaalia ilmiötä, jossa ilmakehän kasvihuonekaasujen määrä kasvaa ihmisen toiminnan seurauksena niin, että maapallon keskilämpötila ylittää kestävän rajan (Holden, 2012; Ilmatieteen laitos, 2018b; IPCC, 2014a). Liian nopeasti lämpenevä ilmasto aiheuttaa maailmanlaajuisesti hyvin merkittäviä ekologisia, sosiaalisia, taloudellisia ja kulttuurisia riskejä, koska ympäristö ei ehdi sopeutua nousevan keskilämpötilan aiheuttamiin muutoksiin riittävän nopeasti (World Meteorological Organization, 2018). Ilmastonmuutos on paitsi ekologinen myös taloudellinen ja yhteiskuntatieteellinen ilmiö (vrt. Cantell ym., 2019; Tolppanen ym., 2017). 
Moni- ja poikkitieteisyytensä vuoksi ilmastonmuutoksen opetus on ongelmallista, sillä sen tulisi perustua eri opettajaryhmien väliseen yhteistyöhön sekä suunniteltaessa koulukohtaisia opetussuunnitelmia että toteutettaessa opetusta (Oversby, 2015). Oppiainejakoiset opetussuunnitelmat ja niiden sisältörunsaus synnyttävät aihevalintoja ja ajankäyttöä koskevia ongelmia (vrt. Wolff, Sjöblom, Hofman-Bergholm \& Palmberg, 2017). Opettajien ilmastonmuutosta koskevat tiedot ovat paitsi puutteellisia usein myös virheellisiä (Boon, 2010; Lambert \& Bleicher, 2013; Puk \& Stibbards, 2012; Ratinen, 2013). Myöskään opettajien pedagogiset tiedot ja taidot eivät välttämättä riitä uudenlaiseen kokonaisvaltaiseen ilmastonmuutoksen opetukseen (Oversby, 2015; Tolppanen, Claudelin \& Kang, 2020). Opetusta vaikeuttaa lisäksi se, että monet opiskelijat pitävät ilmatieteitä eli meteorologiaa muista luonnontieteellisistä aloista poikkeavana eivätkä yhtä eksaktina kuten esimerkiksi fysiikkaa ja kemiaa (Oversby, 2015). Muun muassa edellä selostettujen syiden takia ilmastonmuutoksen opetus tarvitsee entisten lisäksi uusia opetusmenetelmiä.

Uudet opetusmenetelmät voivat pohjata innovatiiviseen pedagogiikkaan, jolle Oversbyn (2015) mukaan on ominaista: (1) sellaiset oppisisältöjä ja asenteita koskevat kysymykset, jotka herättävät halun keskustella asioista tai esittää ja etsiä vaihtoehtoisia käsityksiä, (2) yhteistyönä ilmiöiden seurauksien tarkastelu sekä sellaisten kysymysten keksiminen, joihin ei ole yhtä ainoaa vastausta, (3) oppilaiden omien kysymysten tekeminen ilmiöitä koskevista visuaalisista esitystavoista ja kuvioista, sekä (4) yhteistyöhön perustuvat leikit esimerkiksi hiilen kierrosta. Taidekasvatus, ongelmaperustainen oppiminen, ilmiölähtöinen oppiminen ja ilmastokasvatuksen polkupyörämalli ovat esimerkkejä innovatiivista pedagogiikkaa sisältävistä opetusmenetelmistä, joita käytetään ilmastonmuutoksen opetuksessa.

Taidekasvatus kokonaisvaltaisena ja oppijakeskeisenä opetus- ja opiskelumuotona (Jokela, 1997) voi tukea oppilaan itsetuntemuksen, identiteetin ja empatiakyvyn kehittymistä (vrt. Palmer, 1998). Ilmastonmuutoksen opetuksessa olisikin tärkeää ottaa huomioon oppilaiden tunteet ja kokemukset (Cantell, 2004; Hungerford \& Volk, 1990; Jeronen \& Kaikkonen, 2002; Käpylä, 1995). Empaattinen asenne ja luova ajattelu auttavat ymmärtämään elämismaailman monimutkaisia vuorovaikutussuhteita (McNaughton, 2006; 2010). Ne voivat myös edistää oppilaiden ilmastonmuutosta koskevien käsitysten muotoutumista (Lehtonen, Salonen \& Cantell, 2019) ja ihmisen ympäristöriippuvuuden ymmärtämistä. Ilmastonmuutoksen opetukseen sopivia taidekasvatuksen opetusmenetelmiä ovat esimerkiksi ympäristötaide (Jokela, 1997) ja draamapedagogiikka (McNaughton, 2006; 2010). Niihin sisältyvä kokemuksellinen oppiminen kehittää myös oppilaan käsityksiä ilmastonmuutoksesta, ilmiön luonteesta, ilmenemismuodoista ja seurauksista sekä sitä koskevista mahdollisista toimintatavoista (Pruneau, Gravel, Bourque \& Langis, 2003).

Ongelmaperustaisella oppimisella voidaan tukea systeemistä ja kokonaisvaltaista ajattelua, jota tarvitaan ongelmien pohtimiseen ja ongelmanratkaisujen synnyttämiseen yhteistoiminnallisesti (Jeronen, Palmberg \& Yli-Panula, 2016). Yhdessä toimiminen ja työskentely ovat 
keskeisiä tulevaisuuden taitoja, joita tarvitaan sekä koulussa että yhteisössä (vrt. Pyhältö, Pietarinen \& Soini, 2014). Ongelmaperustaiseen oppimiseen kuuluva suunnitteluvaihe voi auttaa oppilaita ymmärtämään ja omaksumaan erilaisia toimintamahdollisuuksia. Se voi myös lisätä heidän halukkuuttaan toimia ilmastonmuutosta ehkäisevästi (Tolppanen ym., 2020).

Ilmiölähtöisen oppimisen tavoitteena on, että oppilaat rakentavat itselleen oppiaineiden välistä kokonaisvaltaista kuvaa ilmiöistä, jotka liittyvät heidän omaan kiinnostukseensa ja yhteisöönsä (Silander, 2015). Opiskelun tulisi olla yhteisöllistä ja tapahtua todellisissa ympäristöissä koulun ulkopuolella (Wakil \& Rahman \& Hasan \& Mahmood \& Jalal, 2019). Oppilaiden henkilökohtaiset kokemukset, tunteet ja kyvyt kommunikoida yhdessä kunnioittaen toinen toistaan tukevat ilmiölähtöistä oppimista (Pyhältö ym., 2014). Ilmiölähtöisessä oppimisessa (Lonka ym., 2015) ilmastonmuutosta lähestytään opiskelijoiden itsensä esittämien kysymysten avulla, joihin etsitään vastauksia erilaisista lähteistä. Ilmaston moniulotteiseen tarkasteluun tarvitaan luovaa ja kriittistä ajattelua sekä aktivoivia, kokemuksellisia, yhteisöllisiä sekä toimijuutta vahvistavia opetusmenetelmiä. Yhdessä oppimalla ja luovalla ryhmätyöskentelyllä, esimerkiksi taidelähtöisten menetelmien avulla, voidaan jakaa ilmastonmuutoksen herättämiä tunteita ja ajatuksia sekä vahvistaa toivon tunnetta ja uskoa omiin vaikutusmahdollisuuksiin (Lotz-Sisitka, Wals, Kronlid \& McGarry, 2015).

Ilmastokasvatuksen polkupyörämallissa (Cantell ym., 2019; Tolppanen ym., 2017) korostetaan ilmastonmuutoksen opetuksen kokonaisvaltaisuutta unohtamatta kuitenkaan sen osa-alueita, joita ovat: (1) tiedon lisääminen ja jäsentäminen, (2) ajattelun taitojen kehittäminen, (3) identiteetin, arvojen ja maailmankuvan huomioiminen, (4) motivaation ja osallisuuden lisääminen, (5) toimintaan kannustaminen, (6) toiminnan esteiden tiedostaminen, (7) tulevaisuuteen ohjaaminen sekä (8) toivon ja muiden tunteiden herättäminen. Mallissa suositellaan, että tietoa käytetään transformatiivisen oppimisajattelun mukaisesti kriittisesti, vertaillen, analysoiden ja uutta ymmärrystä rakentaen. Ajattelun taitojen kehittämisessä kiinnitetään huomiota systeemiseen tiedon käsittelemiseen. Uudet tiedot ja taidot tulisi kiinnittää oppilaan identiteettiin, arvoihin ja maailmankuvaan. Tämä tarkoittaa keskustelua eettisistä kysymyksistä eri näkökulmista (Tirri, Tolppanen, Aksela \& Kuusisto, 2012). Toimintaa ilmastonmuutoksen hillitsemiseksi tulisi tarkastella motivaation ja osallisuuden sekä toimintamahdollisuuksien näkökulmasta miettimällä, miten toimintaa voidaan tehostaa esimerkiksi lisäämällä tietoisuutta toiminnan esteistä (Tolppanen, 2015). Tulevaisuuden pohtiminen ja visioiminen sisältävät sellaistenkin päätösten tekemisen harjoittelua, joiden oikeellisuudesta ei ole täyttä varmuutta (Sterling, 2010). Realistisen toivon rakentuminen on tärkeä tavoite ilmastonmuutoksen opetuksessa. Se on mahdollista, kun kohdataan erilaisia haasteita ja haasteista huolimatta opitaan uskomaan omiin vaikutusmahdollisuuksiin (Hicks, 2014; Pihkala, 2017). Omiin vaikutusmahdollisuuksiin uskomista (ja oppimista yleensäkin) voivat vaikeuttaa esimerkiksi rajoittuneet tiedonkäsittelyprosessit ja ajattelun taidot. Ilmastonmuutoksen opetuksella olisikin mahdollisuus 


\section{Ainedidaktiikka 4(3) (2020)}

kehittää oppilaiden valmiuksia epävarmuuden kohtaamiseen, tulevaisuuden ajattelutaitojen oppimiseen ja omien vaikutusmahdollisuuksien tiedostamiseen.

\section{Tiedon ja ajattelun tasot ilmastonmuutoksen opetuksessa}

Tiedon tasot voidaan jakaa faktatietoon, jolla tarkoitetaan oppiaineelle ominaista asiasisältötietoa, oppiaineen käsitetietoa ja menetelmätietoa sekä metakognitiivista tietoa (Anderson ym., 2001; Kärnä, Houtsonen \& Tähkä, 2012; Tikkanen, 2010). Nämä tiedon tasot pätevät kaikkiin luonnontieteisiin ja alla niitä esitellään biologian ja maantieteen näkökulmasta. Ilmastonmuutoksen opetuksen sisältötieto biologiassa ja maantieteessä sisältää esimerkiksi terminologista tietoa kasvihuonekaasuista, perustavaa tietoa vaikkapa suomalaisten keskimääräisestä hiilijalanjäljestä ja kasvihuonepäästöjä tuottavista kaupungeista (taulukko 1).

Taulukko 1. Tiedon tasot mukailtuna ilmastonmuutoksen opetukseen (vrt. Anderson ym., 2001; Kärnä ym., 2012; Tikkanen, 2010)

\begin{tabular}{ll}
\hline Päätaso & Alataso \\
\hline A1. Tieto terminologiasta \\
A. Faktatieto & $\begin{array}{l}\text { A2. Tieto tarkoista yksi- } \\
\text { tyiskohdista ja perusele- } \\
\text { menteistä }\end{array}$ \\
& $\begin{array}{l}\text { B1. Tieto luokituksista ja } \\
\text { kategorioista } \\
\text { B2. Tieto periaatteista ja } \\
\text { yleistyksistä } \\
\text { B3. Tieto teorioista, } \\
\text { malleista ja rakenteista }\end{array}$
\end{tabular}

Esimerkkejä

kasvihuonekaasut

suomalaisen hiilijalanjälki, eniten kasvihuonepäästöjä tuottavat kaupungit ja kasvihuonekaasujen kemialliset kaavat.

ilmastonmuutokseen liittyvät geologiset ajanjaksot

hiilen kierto, kasvihuoneilmiö energian säilymislaki, planetaarisuuden teoriat

C1. Tieto oppiainekohtaisista taidoista ja algoritmeista

C. Menetelmätieto

C2. Tieto oppiainekohtaisista tekniikoista ja metodeista

D1. Strateginen tieto

D. Metakognitiivinen tieto
D2. Tieto tarkoituksenmukaisen kontekstuaalisen ja konditionaalisen tiedon sisältävistä kognitiivisista tehtävistä työtavat laboratoriossa, kenttätyössä tai sähköisissä sovelluksissa (kuten paikkatietojärjestelmät), laskujen ratkaisutavat

ongelmanratkaisumenetelmät, tutkimusmenetelmät, systeeminen tulevaisuus-ajattelumenetelmät

tieto kokeellisten menetelmien suunnittelusta, tiedon järjestäminen

tieto siitä, milloin mitäkin menetelmää käytetään 
Käsitetietoon liitetään tieto luokituksista esimerkkinä kasvihuonekaasupäästöjen jaottelu sekä tieto periaatteista kuten hiilen kierrosta ja planetaarisuuteen liittyvistä teorioista. Menetelmätiedot kattavat oppiainekohtaiset taidot, tekniikat sekä tiedon menetelmien käytöstä. Tällaisia tietoja vaatii muun muassa karttaohjelmien ja niihin liittyvien kuvaajien hyödyntäminen ilmastonmuutoksen alueellisessa tutkimuksessa. Metakognitiivinen tieto taas auttaa oppilasta käsittelemään uutta tietoa ja itseään oppijana ja ihmisenä. Ilmastonmuutoksen opiskelussa metakognitiivisen tiedon tunnistaminen saattaa vaikuttaa oppilaan itsetuntemukseen ja myös oppilaan arvoihin.

Ajattelun tasoja voidaan tarkastella alemman (LOCS, Lowerorder cognitive skills) ja korkeamman tason (HOCS, Higher-order cognitive skills) toimintoina (Aksela, Tikkanen \& Kärnä, 2012; Krathwohl, 2002). Alempia ajattelun tasoja ovat tunnistaminen, ymmärtäminen ja soveltaminen; korkeamman ajattelun tasoja taas ovat analysointi (erottelu, jäsentäminen ja piilomerkitysten havaitseminen), arviointi ja luominen (Aksela, Tikkanen \& Kärnä, 2012; Krathwohl, 2002).

Tunnistamisen tasolla oppilas hakee tietoa muistista esimerkiksi eniten ympäristöä kuluttavista maista tai mieleen palauttamisen tasolla kemiallisista symboleista, joita käytetään kasvihuonekaasujen merkinnöistä (liite 1, taulukko 1). Ymmärtämisen tasolla oppilas osaa tulkita, kertoa esimerkkejä, luokitella, tehdä yhteenvetoja, päätellä, vertailla ja perustella ilmastomuutokseen liittyviä asioita. Oppilas osaa muun muassa esitellä esimerkein hiilen lähteitä, vertailla niitä toisiinsa ja muodostaa yhteenvedon hiilidioksidin tuottajista ilmastonmuutoksen kannalta. Soveltamisen taso liittyy menetelmätiedon käyttöön eli joko yhden tai useamman menetelmän toteuttamiseen. Toisin sanoen oppilaan täytyy esimerkiksi ymmärtää, miten karttaohjelmaa käytetään ilmastonmuutosta koskevien tehtävien ratkaisemiseen.

Korkeammista ajattelun tasoista analysointi ja arviointi sisältävät sekä ilmastonmuutostiedon tarkistamisen (esimerkiksi ovatko ilmastonmuutoksen yhteydessä esitellyt prosessit johdonmukaisia ja virheettömiä) että tuotteen arvioinnin (esimerkiksi täyttääkö tuote sille asetetut ulkoiset kriteerit tai standardit). Luomisen tasolla taas oppilas osaa kehittää, suunnitella ja tuottaa uutta aikaisemman tietonsa pohjalta. Korkeammat ajattelun tasot kehittyvät oppilaissa vähitellen, niitä on vaativaa mitata ja niitä tukee vahvasti vain osa opetusmenetelmistä.

\section{Tutkimusmenetelmät}

\section{Artikkelien valinta}

Systemaattisen arvioinnin lähtökohtana on, että tiettyjä vaiheita noudattaen päädytään toistettaviin tuloksiin (Cooper, 2010; Gough, Oliver \& Thomas, 2012). Tämä tutkimus perustuu systemaattisen arvioinnin prosessiin. Aineisto kerättiin käyttäen ERIC ja Education Research Complete 
-tietokantoja. Aineiston valinnan kriteerit olivat: kansainväliset vertaisarvioidut artikkelit vuosilta 2000-2019, ilmastonmuutoksen opetusmenetelmät sekä peruskoululaiset ja lukiolaiset. Hakusanat (esim. muotoa geograph* OR biolog*, liite 1, taulukko 2) pohjasivat ilmastonmuutoksen opetusmenetelmiin joko biologiassa tai maantieteessä ja luokka-asteeseen.

Haussa hyväksytyiksi tulivat ne artikkelit (ks. lähteissä analysoidut artikkelit), joissa edellä mainitut hakusanat mainittiin ainakin jossakin kohden artikkelia. Lisäksi aineiston valinnan kriteereistä vähintään kahden tuli täyttyä otsikon ja tiivistelmän kohdalla. Näiden kriteerien varmistamiseksi saadut artikkelit käytiin läpi myös manuaalisesti. Artikkelin kieltä ei rajoitettu, mutta käytännössä kaikki käsiteltävät artikkelit oli kirjoitettu englannin kielellä.

Tarkempaan analyysiin valikoitui 14 artikkelia $(\mathrm{N}=159)$ ja ne oli julkaistu kymmenessä eri julkaisusarjassa (taulukko 2). Karsitut artikkelit eivät toteuttaneet opetusmenetelmäkriteeriä eli ne eivät käsitelleet ilmastonmuutosta opettamisen tai oppimisen näkökulmasta. Valituista 14 artikkelistakin 11 käsitteli pääasiallisesti ilmastonmuutoksen opetuksessa käytettyjä opetusmenetelmiä ja loput kolme artikkelia ympäristökasvatuksen tai kestävän kehityksen opetusmenetelmiä, joissa ilmastonmuutos oli vain yhtenä opetettavana aiheena.

Taulukko 2. Artikkelien julkaisusarjat (numerot tarkoittavat artikkeleiden analyysinumeroita)

\begin{tabular}{lc}
\hline \multicolumn{1}{c}{ Tieteelliset lehdet } & Artikkelit \\
\hline Applied Environmental Education and Communication & 5 \\
Education Science & 1 \\
Environmental Education Research & 4,8 \\
International Journal of Environmental and Science Education & 6 \\
International Research in Geographical and Environmental Education & 13,14 \\
Journal of Geography & 12 \\
Journal of Geoscience Education & 11 \\
Journal of Research in Science Teaching & 3 \\
Science Education International & 9 \\
The Science Teacher & $2,7,10$ \\
\hline
\end{tabular}

\section{Analysointimenetelmät}

Aluksi artikkelit analysoitiin aineistolähtöistä ja teoriaohjaavaa sisällönanalyysia käyttäen oppiaineen (biologia ja maantiede, joka sisältää tässä myös yläkoulun maantieto-oppiaineen), oppilaiden luokka-asteen (yläkoulu ja lukio) ja opetusaiheen perusteella. Yksityiskohtaisempi analysointi keskittyi opetusmenetelmien erilaisuuden tai samankaltaisuuden tarkasteluun, ja opetusmenetelmien oppimista edistävän tason analyysiin.

Ilmastonmuutoksen opetuksessa käytettyjen opetusmenetelmien analysointi (tutkimuskysymys 1) pohjattiin Elorannan, Jerosen ja Palmbergin (2005) kirjassa esitettyihin biologian oppiaineen opetusmenetelmiin, 
jotka ovat yleistettävissä muiden oppiaineiden opetusmenetelmiin. Artikkeleissa esiintyvät opetusmenetelmät listattiin ja sopivan yläkäsitteen puuttuessa muodostettiin uusi yläkäsite.

Selvitettäessä sitä, miten opetusmenetelmät tukevat ilmastonmuutoksen oppimista, kaksi tutkijaa tarkasteli itsenäisesti artikkeleissa esitettyjä opetusmenetelmiä, niiden tiedon ja ajatteluntasoja (Aksela, Tikkanen \& Kärnä, 2012; Krathwohl, 2002). Lopuksi koottiin lista näiden kahden tutkijan yhteisten kriteerien pohjalta aineiston ilmastonmuutoksen opetuksessa käytettyjen opetusmenetelmien osaamista kehittävistä ominaisuuksista.

\section{Tulokset}

\section{Ilmastonmuutoksen opetuksessa käytetyt opetusmenetelmät ja oppi- sisällöt}

Analysoiduista 14 artikkelista kuudessa esiteltiin ilmastonmuutoksen opetuksessa käytettyjä opetusmenetelmiä biologian, kuudessa maantieteen ja kahdessa sekä biologian että maantieteen näkökulmasta. Kahdessa biologian artikkelissa opetusmenetelmä oli linkitetty kemian ja fysiikan opetukseen. Kolmessa artikkelissa ilmastonmuutoksen opetus kohdistui yläkoulun oppilaisiin (vuosiluokat 8 ja 9), yhdessä sekä lukiolaisiin että yläkoululaisiin, ja loput kymmenen lukiolaisiin.

Ilmastonmuutoksen opetuksessa käytettiin melko monipuolisesti erilaisia opetusmenetelmiä (taulukko 3). Tulosten perusteella käytetyimmät opetusmenetelmät olivat kyselevä opetus ja opetuskeskustelu $(\mathrm{N}=9)$ sekä ryhmätyö $(\mathrm{N}=7)$. Muita runsaasti käytettyjä opetusmenetelmiä olivat ongelmalähtöinen oppiminen $(\mathrm{N}=6)$, tutkiva oppiminen $(\mathrm{N}=2)$ ja lyhyet maastokäynnit $(\mathrm{N}=2)$. Useimmat artikkeleissa käytetyt opetusmenetelmät kuuluivat tutkivaan oppimiseen ja ongelmanratkaisuun perustuviin työtapoihin $(\mathrm{N}=22)$. Myös opettajakeskeisen opettamisen menetelmät $(\mathrm{N}=12)$ olivat yleisiä.

Taulukko 3. Artikkelien sisältämät ilmastonmuutoksen opetuksessa käytetyt opetusmenetelmät ja niiden yhteislukumäärät (artikkeleiden analyysinumeroiden perässä b tarkoittaa biologiaa ja m maantiedettä)

\begin{tabular}{llc}
\hline Opetusmenetelmät & Artikkelit & Yhteensä \\
\hline Opettajakeskeinen opettaminen & & $\mathbf{1 2}$ \\
Kyselevä opetus ja opetuskeskustelu & $\begin{array}{l}2 \mathrm{~b}, 5 \mathrm{~b}, 6 \mathrm{~b}, 7 \mathrm{~m}, \\
8 \mathrm{bm}, 10 \mathrm{bm}, 12 \mathrm{~m},\end{array}$ & 9 \\
& $13 \mathrm{~m}, 14 \mathrm{~m}$ & \\
Esittävä opetus & $4 \mathrm{~m}, 5 \mathrm{~b}, 7 \mathrm{~m}$ & 3 \\
& & $\mathbf{2 2}$ \\
$\begin{array}{l}\text { Tutkivaan oppimiseen ja ongelmanratkai- } \\
\text { suun perustuvat työtavat }\end{array}$ & & \\
Ryhmätyö & $1 \mathrm{~m}, 2 \mathrm{~b}, 5 \mathrm{~b}, 6 \mathrm{~b}, 11 \mathrm{~b}$, & 7
\end{tabular}


Ainedidaktiikka 4(3) (2020)

Ongelmalähtöinen oppiminen

Tutkiva oppiminen

Tehtäviin painottuva työskentely

Mallin luominen ja käsitekartat

Projektityöskentely

Laboroinnit ja kokeilut tutkivan ja ongelmakeskeisen oppimisen työtapoina

Demonstraatiot

Maasto-opetus ja kenttätyöt

Lyhyet maastokäynnit

Yhteistoiminnallinen oppiminen

Yhteistoiminnallinen oppiminen

Palapelimenetelmät

Muut opetusmenetelmät

Roolileikit ja argumentaatioharjoitukset

Tietokoneavusteinen opetus

Mielen mallit

Videopelit

Videonteko

Piirtäminen

Runoanalyysi
$3 \mathrm{~b}, 5 \mathrm{~b}, 6 \mathrm{~b}, 9 \mathrm{~b}, 13 \mathrm{~m}$, $14 \mathrm{~m}$

$5 \mathrm{~b}, 6 \mathrm{~b}$ 2

$11 \mathrm{~b}, 13 \mathrm{~m}, 14 \mathrm{~m}$

$3 \mathrm{~b}, 12 \mathrm{~m}$

$1 \mathrm{~m}, 7 \mathrm{~m}$

$1 \mathrm{~m}$

$9 \mathrm{~b}-1$

Tarkasteltaessa ilmastonmuutoksen opetuksessa käytettyjä opetusmenetelmiä oppiaineittain havaittiin, että biologian ilmastonmuutoksen opetuksessa oli käytetty 11 erilaista opetusmenetelmää (taulukko 3), joista käytetyimmät olivat kyselevä opetus ja opetuskeskustelu $(\mathrm{N}=5)$ sekä ryhmätyö $(\mathrm{N}=4)$. Biologian tapaan myös maantieteessä ilmastonmuutosta käsiteltiin artikkeleissa useimmiten kyselevän opetuksen ja opetuskeskustelun $(\mathrm{N}=6)$ sekä ryhmätöiden $(\mathrm{N}=3)$ avulla. Maantieteessä oli käytetty 17 erilaista ilmastonmuutoksen oppimista edistävää opetusmenetelmää. Muita opetusmenetelmiä kuten roolipelejä ja argumentaatioharjoituksia sekä tietokoneavusteista opetusta käytettiin maantieteessä useammin kuin biologiassa. Opetuksessa käytettiin useita opetusmenetelmiä yhdessä, esimerkkinä viidennen artikkelin kyselevä opetus ja opetuskeskustelu, esittävä opetus, ryhmätyö, ongelmalähtöinen oppiminen, tutkiva oppiminen ja maastokäynnit.

Ilmastonmuutos oli oppisisältönä 11 artikkelissa ja loput kolme artikkelia käsittelivät ilmastonmuutoksen vaikutuksia kestävän kehityksen 
Ainedidaktiikka 4(3) (2020)

näkökulmasta (taulukko 4). Täysin ilmastonmuutoksen opetukseen keskittyvät artikkelit käsittelivät ilmastonmuutosta pääasiallisesti ilmastonmuutoksen selittämisen tai vaikutusten kautta (artikkelit 2, 7, 8, 11, 12 ja 14). Muita käsittelytapoja olivat hiilen kierto (artikkelit 3 ja 5), paleoekologia (artikkeli 6), bioetanoli (artikkeli 9) ja kasvihuoneilmiö (artikkeli 13). Kestävää kehitystä käsittelevät artikkelit edustivat ilmastonmuutoksen opetuksessa käytettyjä opetusmenetelmiä koskien kestävän kehityksen tavoitteita (artikkeli 1), kestävää kaupunkikehitystä (artikkeli 4) ja fossiilisten polttoaineiden kulutusta ja maataloutta (artikkeli 10).

Taulukko 4. Ilmastonmuutoksen opetuksen sisällöt artikkeleittain (numerot tarkoittavat artikkeleiden analyysinumeroita)

\begin{tabular}{llc} 
Oppiaihe & \multicolumn{1}{c}{ Oppiaiheen tarkempi sisältö } & Artikkelit \\
\hline $\begin{array}{l}\text { Kestävä } \\
\text { kehitys }\end{array}$ & Kestävän kehityksen tavoitteet & 1 \\
& Kestävä kaupunkikehitys & 4 \\
& Fossiilisten polttoaineiden kulutus ja maatalous & 10 \\
\hline $\begin{array}{l}\text { Ilmaston- } \\
\text { muutos }\end{array}$ & Ilmastonmuutoksen vaikutukset eri alueisiin, erityisesti & 2 \\
& napa-alueisiin & 5 \\
& Hiilen kierto, puun hiilipitoisuus & 6 \\
& Paleoekologia & 7 \\
& Ilmastonmuutoksen vaikutukset paikallisella tasolla & 8 \\
& Ilmastonmuutos: ihmisen vaikutus, ilmastonmuutoksen & 9 \\
& alueelliset vaikutukset & \\
& Bioetanoli vaihtoehtoisena polttoaineena & 11 \\
& Ilmastonmuutos: ekosysteemit, deforestaatio, ilmaston- & 12 \\
& muutoksen vaikutukset luontoon & 13 \\
& Ilmastonmuutoksen vaikutukset paikallisella tasolla & 14 \\
\hline & Kasvihuoneilmiö &
\end{tabular}

Hiilen kiertokulun opettamista käsiteltiin kahdessa artikkelissa. Vaikka ilmastonmuutokseen vaikuttaminen oli monien artikkeleissa käytettyjen opetusmenetelmien osana, niissä ei kuitenkaan käsitelty pääasiana seuraavia aiheita: eri lajien ympäristöön sopeutumista, ympäristöongelmia ja monimuotoisuuden vähenemistä, ei myöskään biologian opetuksen roolia ilmastonmuutoksen hidastamisessa ja siihen vaikuttamisessa.

Maantieteessä kestävän kehityksen ja ympäristökasvatuksen merkitys korostui ilmastonmuutoksen opetuksessa. Yhden artikkelin keskeisimpänä aihesisältönä oli sekä biologian että maantieteen kannalta oleellinen ilmastonmuutosta koskeva asia: se, ettei ilmaston muuttuminen ole yksinomaan ihmisten aikaansaama ilmiö, vaan ilmasto muuttuu luonnollisesti pitkän ajan kuluessa. 


\section{Tiedon ja ajattelun tasot ilmastonmuutoksen opetuksessa}

Artikkeleissa käsiteltiin ilmastonmuutosta koskevia tietoja vaihtelevasti eri tiedon tasoilta (taulukko 5). Kaikissa artikkeleissa käsiteltiin tietoa ilmastonmuutoksen yksityiskohdista ja peruselementeistä (A2). Suurimmassa osassa artikkeleita käsiteltiin myös faktatietoa ilmastonmuutoksen terminologiasta (A1) sekä käsitetietoa (B) ja menetelmätietoa (C) ilmastonmuutoksesta. Metakognitiivista tietoa (D) oli strategisen tiedon (D1) ja itsetuntemuksen (D3) osalta noin puolessa artikkeleista. Vain kolmessa artikkelissa oli kognitiivisia tehtäviä sidottuna tarkoituksenmukaiseen asiayhteyteen ja konditionaaliseen tietoon (D2).

Taulukko 5. Tiedon tasot ja niiden yhteislukumäärä ilmastonmuutoksen opetuksessa artikkeleittain (numerot tarkoittavat artikkeleiden analyysinumeroita)

\begin{tabular}{|c|c|c|c|}
\hline Päätaso & Alataso & Artikkelit & Yhteensä \\
\hline \multirow[t]{2}{*}{ A. Faktatieto } & $\begin{array}{l}\text { A1. Tieto terminologi- } \\
\text { asta }\end{array}$ & $\begin{array}{l}1,2,3,5,6,7,8,9 \\
10,13,14,15,16\end{array}$ & 13 \\
\hline & $\begin{array}{l}\text { A2. Tieto tarkoista yksi- } \\
\text { tyiskohdista ja perusele- } \\
\text { menteistä }\end{array}$ & $\begin{array}{l}1,2,3,4,5,6,7,8 \\
9,10,11,12,13,14\end{array}$ & 14 \\
\hline \multirow[t]{3}{*}{ B. Käsitetieto } & $\begin{array}{l}\text { B1. Tieto luokituksista ja } \\
\text { kategorioista }\end{array}$ & $\begin{array}{l}1,2,3,5,6,7,8,9 \\
11,12,13,14\end{array}$ & 12 \\
\hline & $\begin{array}{l}\text { B2. Tieto periaatteista ja } \\
\text { yleistyksistä }\end{array}$ & $\begin{array}{l}2,3,4,5,6,7,8,9 \\
10,11,12,13,14\end{array}$ & 13 \\
\hline & $\begin{array}{l}\text { B3. Tieto teorioista, mal- } \\
\text { leista ja rakenteista }\end{array}$ & $\begin{array}{l}3,5,6,8,9,11,12 \\
13,14\end{array}$ & 9 \\
\hline \multirow[t]{2}{*}{ C. Menetelmätieto } & $\begin{array}{l}\text { C1. Tieto oppiainekoh- } \\
\text { taisista taidoista ja algo- } \\
\text { ritmeista }\end{array}$ & $\begin{array}{l}1,5,6,7,8,9,10 \\
11,12,13,14\end{array}$ & 11 \\
\hline & $\begin{array}{l}\text { C2. Tieto oppiainekoh- } \\
\text { taisista tekniikoista ja } \\
\text { metodeista }\end{array}$ & $\begin{array}{l}1,5,6,7,8,9,12 \\
14\end{array}$ & 8 \\
\hline \multirow[t]{3}{*}{$\begin{array}{l}\text { D. Metakognitiivinen } \\
\text { tieto }\end{array}$} & D1.Strateginen tieto & $\begin{array}{l}1,3,6,7,8,9,12 \\
13,14\end{array}$ & 9 \\
\hline & $\begin{array}{l}\text { D2. Tieto tarkoituksen- } \\
\text { mukaisen kontekstuaali- } \\
\text { sen ja konditionaalisen } \\
\text { tiedon sisältävistä kogni- } \\
\text { tiivisista tehtävistä }\end{array}$ & $9,12,14$ & 3 \\
\hline & D3. Itsetuntemus & $\begin{array}{l}1,2,4,8,9,11,12 \\
14\end{array}$ & 8 \\
\hline
\end{tabular}




\section{Ainedidaktiikka 4(3) (2020)}

Lähes kaikki artikkeleissa esitetyt ilmastonmuutoksen opetuksessa käytetyt opetusmenetelmät tukivat ajattelun alimpia tasoja ja yli puolet ylempiä tasoja (taulukko 6). Alle puolet opetusmenetelmistä tuki korkeinta ajattelun tasoa.

Taulukko 6. Ajattelun tasot ja niiden lukumäärät ilmastonmuutoksen opetuksessa artikkeleittain (numerot tarkoittavat analysoitujen artikkeleiden numeroita; LOCS eli Lower-order cognitive skills ja HOCS eli Higherorder cognitive skills tarkoittavat alempia ja korkeampia ajattelun tasoja)

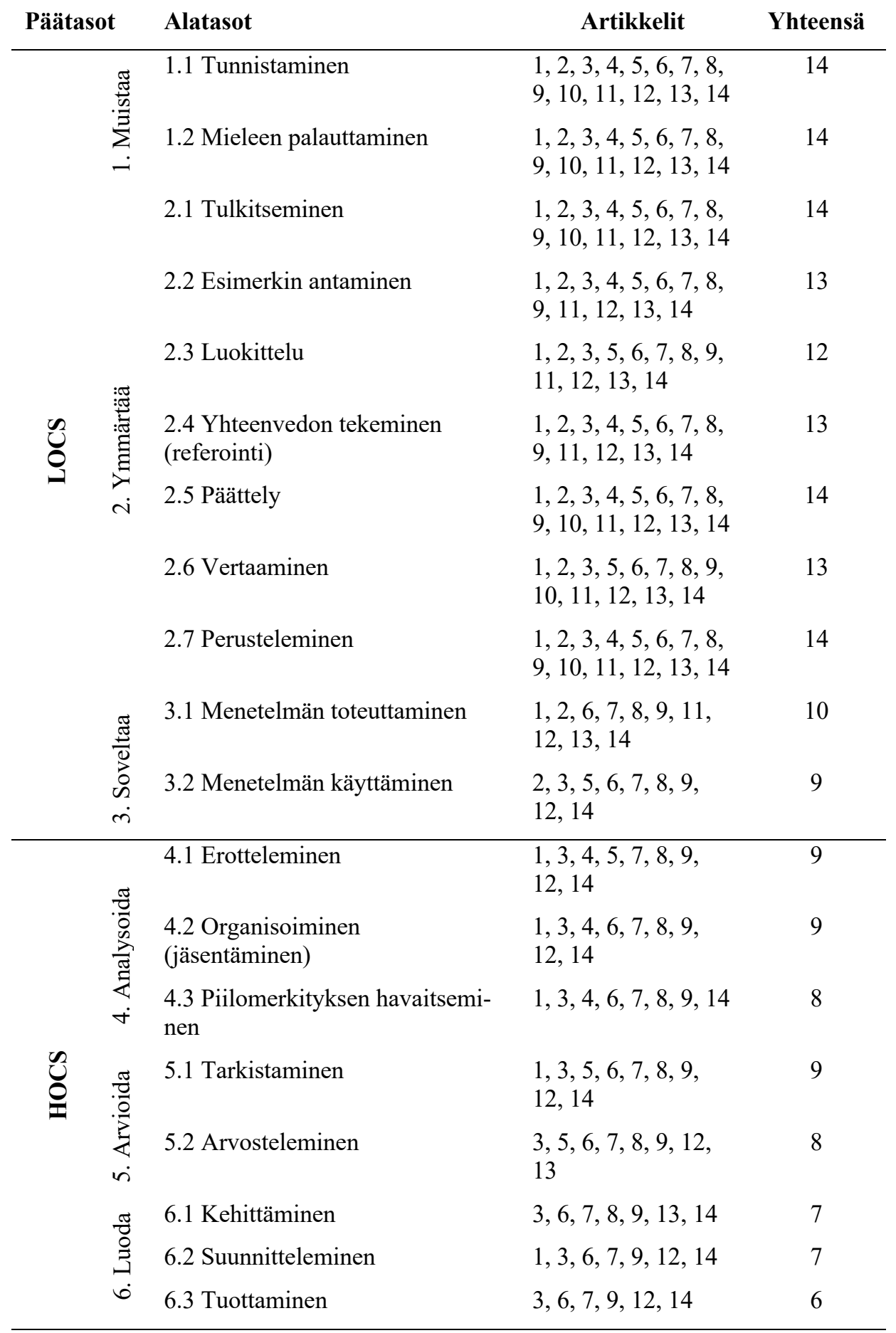


Tarkasteltaessa artikkeleissa esiintyviä eri tiedon ja ajattelun tasojen suhteellista esiintymistä yläkoulussa ja lukiossa niiden havaittiin jakautuvan suhteellisen tasaisesti. Ainoat poikkeukset muodostivat tiedon tasoista yläkoulun runsaampi käsitetiedon ja lukion korkeampi menetelmätiedon taso sekä luovan ajattelun taso, jota oli lukiossa vain $6,8 \%$ ja yläkoulussa $11,5 \%$.

\section{Tulosten tarkastelu}

Tutkimuksen tavoitteena oli kartoittaa artikkeleita koskevan sisällönanalyysin avulla ilmastonmuutoksen opettamiseen liittyviä opetusmenetelmiä ja niiden avulla opetettavia asiasisältöjä ja opetusmenetelmien tukemia tiedon ja ajattelun tasoja biologiassa ja maantieteessä. Yleisimmin artikkeleissa käytetyt opetusmenetelmät olivat tutkivaan oppimiseen ja ongelmaratkaisuun perustuvat opetusmenetelmät, ryhmätyöt ja opettajakeskeiset opetusmenetelmät. Maantieteessä käytettiin biologiaa monipuolisemmin erilaisia ilmastonmuutoksen opiskelua edistäviä opetusmenetelmiä. Opetusmenetelmät tukivat harvemmin korkeampia tiedon tasoja kuten menetelmätietoa sekä metakognitiivista tietoa ja korkeampia ajattelun tasoja kuten synteesin tekoa tai arviointia verrattuna alempiin tasoihin.

Biologian ja maantieteen oppisisällöt ja niihin liittyvien opetusmenetelmien tarkastelu oli yksi tutkimuksen kohde. Biologiassa käsiteltäväksi ilmastonmuutoksen oppisisällöksi (Open ilmasto-opas, 2019b) oli listattu muun muassa hiilen kiertokulku, mikä toteutui kahdessa analysoidussa artikkelissa. Muun muassa kestävän kehityksen ja ympäristökasvatuksen suuri merkitys korostui ilmastonmuutosopetuksessa. Yhdessä artikkelissa toteutui sekä biologian että maantieteen kannalta keskeinen ilmastonmuutosta koskeva asia - se, että ilmasto muuttuu luonnollisesti pitkän ajan kuluessa eikä ole siis yksinomaan ihmisten aikaansaama ilmiö. Sekä biologian että maantieteen ilmastonmuutoksen opetuksessa käytetyt opetusmenetelmät tukivat ilmastonmuutoksen tietoon, taitoihin ja käsitteisiin liittyvää oppimista. Ilmastonmuutoksen opettaminenhan riippuu korkealaatuisen sisältötiedon opettamisen lisäksi myös pedagogisesta sisältötiedosta, mikä tarkoittaa opettajien tulkintoja ja sisältötiedon muokkaamista oppilaiden oppimista tukevaan muotoon (Shulman, 1986).

Ilmastonmuutoksen opetuksessa käytettiin useita menetelmiä yhdessä tukemaan monimutkaisten asioiden oppimista. Tulos on linjassa aikaisempien tutkimustulosten kanssa koskien kestävän kehityksen opetusta kyseisissä oppiaineissa (Jeronen ym., 2017; Yli-Panula, Jeronen, Lemmetty \& Pauna, 2018; Yli-Panula, Jeronen \& Lemmetty, 2020). Tutkimuksessa havaittiin, että useimmat käytetyistä opetusmenetelmistä liittyivät tutkivaan oppimiseen ja ongelmanratkaisuun. Kyseiset opetusmenetelmät ovat luonnontieteille ominaisia, ja ilmastonmuutos itsessään on luonteeltaan ongelmanratkaisutaitoja vaativaa (Eloranta ym., 2005; Hyppönen \& Lindén, 2009). Aktiiviset opetus-oppimisprosessit ovat tutkimusten mukaan parantaneet asioiden muistiin palauttamista (Cooper, 2000; Grant, 1997), lisänneet motivaatiota ja korkeamman tason oppimista (Kern \& Carpenter, 1986) sekä kartuttaneet käytännön taitoja (Kent, 
Gilbertson \& Hunt, 1997). Näitä kaikkia tarvitaan ilmastonmuutoksen opettamisessa ja oppimisessa.

Haubrich (2007) puolestaan suosittelee ryhmätöitä ja keskustelevaa opetusta sopiviksi menetelmiksi esimerkiksi ekologisten asioiden oppimiseen. Omien kokemusten jakaminen ja päättely ryhmässä tukee opiskelijoiden oman ajattelun ymmärtämistä (Duschl, 2008) ja näin kriittistä ajattelua ja sitoutumista science-aineiden opiskeluun. Kyvykkyys kriittiseen ajatteluun on kompetenssi, jota tarvitaan kestävän kehityksen sisältöjen kuten ilmastonmuutoksen opettamisessa (Unesco, 2017). Sitä pidetään myös ilmastonmuutoksen kaltaisten yhteiskuntatieteellisten sisältöjen oppimisen edellytyksenä.

Brundiersin ja Wiekin (2017) mukaan kestävän kehitykseen liittyvien asioiden keskeisiä osaamistaitoja ovat eheyttävä sisältötieto, menetelmätieto ja menetelmätaito. Analysoiduissa artikkeleissa ilmastonmuutoksen opetuksessa käytetyt opetusmenetelmät tukivat eheyttävän biologian ja maantieteen tiedon osalta sisältö- ja käsitetiedon oppimista, mutta harvemmin korkeampien tiedon tasojen oppimista kuten menetelmätiedon tai metakognitiivisen tiedon oppimista. Metodeista, taidoista, tekniikoista ja niiden käyttökriteereistä koostuva menetelmätieto on tärkeää. Transformatiivisen oppimisajattelun mukaisesti ilmastonmuutokseen liittyvää tietoa tulee soveltaa analysoiden ja vertaillen ja uutta ymmärrystä rakentaen (Cantell ym., 2019) ja tällöin menetelmä- ja metakognitiivisen tiedon tärkeys korostuu. Hermans (2015) on puolestaan todennut tutkimuksessaan, että opiskelijat eivät pystyneet yhdistämään ilmastonmuutosta omaan käyttäytymiseensä. Tämä tulos tukee myös metakognitiivisen tiedon sisäistämisen tärkeyttä ilmastonmuutoksen monimutkaisten asioiden oppimisessa. Analysoiduissa artikkeleissa käytetyt opetusmenetelmät tukivat myös harvemmin ajattelun korkeampia tasoja, analysointia, arviointia ja luovuutta. Tulos herättää kysymyksiä, sillä tutkimusten mukaan sekä luokanopettajat (McMillan, Myran \& Workman, 2002) että aineenopettajat (McMillan, 2001) kertovat käyttävänsä kyseisiä opetusmenetelmiä varsin usein. Alempien ajattelutasojen kysymysten ja tehtävien laatiminen on vaivatonta ja toisaalta yksinkertaisiin kysymyksiin oppilaiden on helppo vastata, joten niitä suositaan juuri näiden ominaisuuksien takia.

Aineiston sisältämät monipuoliset opetusmenetelmät ovat käytössä Suomen kouluissa, joten tutkimuksen tulokset tukevat suoraan biologian ja maantieteen opettamista ja oppimista (Opetushallitus, 2014; 2015; 2019). Suomen kouluissa keskeinen tietokoneavusteinen opetus oli artikkeleissa käytettyjen opetusmenetelmien joukossa, mutta maantieteelle tyypillistä paikkaperustaista opetusta ei mainittu, vaikka ilmastonmuutokseen liittyvät asiat ovat paikkaan sidottuja. Maantieteessä opetusmenetelmiä käytettiin monipuolisemmin ja luovemmin kuin biologiassa, jossa painopiste oli perinteisissä luonnontieteiden opetusmenetelmissä.

Kouluasteiden välillä suurimmat eroavuudet koskivat tiedon tasoja: yläkoulun runsaammassa käsitetietojen ja lukion runsaammassa menetelmätietojen esiintymisessä analysoiduissa opetusmenetelmissä. Tämä tulos on linjassa Suomen koulujen biologian ja maantieteen opetussuunnitelmien sisältöjen (Opetushallitus, 2014; 2015; 2019) kanssa. Lukion oppiaineissa painotetaan tieteellistä ajattelua ja siihen liittyvää oppiaineen tiedon hankintaa oppiaineelle tyypillisten tutkimusmenetelmien kautta. 


\section{Ainedidaktiikka 4(3) (2020)}

Koska artikkelien määrä jakautui varsin epätasaisesti yläkoulun ja lukion kesken (lukiolaisten opetukseen liittyviä artikkeleita oli selvästi enemmän), ei luotettavaa johtopäätöstä voida tehdä siitä, että yläkoulun ilmastonmuutoksen opetuksessa luovaa ajattelutasoa esiintyisi lukion opetusta useammin.

Tutkimuksen luotettavuutta pyrittiin lisäämään lukuisilla hakusanayhdistelmillä ja kahden henkilön itsenäisesti tekemällä artikkelien analyysillä sekä käyttämällä aineistolähtöistä sekä teoriaohjaavaa analyysiä. Toisinaan oli vaikea rajata tarkasti, milloin oli kyse kestävästä kehityksestä ja milloin ilmastonmuutoksen opetuksesta ja sen yhteiskuntatieteellisestä luonteesta. Oppilaiden oma mielenkiinto ilmastonmuutokseen tuli esiin useissa artikkeleissa ja omalla mielenkiinnolla todettiin lähes poikkeuksetta olevan positiivinen vaikutus oppimistuloksiin. Vaikka tässä tutkimuksessa ei tutkittu väärinkäsityksiä, niitäkin löytyi. Esimerkiksi liiallisen yleistämisen seurauksena ja kokonaisuuden hahmottamisen puuttuessa kaikkien ilmansaasteiden oletettiin aiheuttavan ilmaston lämpenemistä. Näitä asioita olisi mielenkiintoista tutkia jatkossa.

Yhteenvetona ilmastonmuutoksen opetuksesta todettakoon, että sen kokonaisvaltaisen ja eheyttävän luonteen vuoksi tulee käyttää monipuolisesti sellaisia opetusmenetelmiä, jotka tukevat sekä eri tiedon- ja ajattelun tasoja että transformatiivista oppimista.

\section{Lähteet}

\section{Analysoidut artikkelit}

1. Álvarez-Otero, J. \& Luisa de Lázaro, M. (2018). Education in Sustainable Development Goals using the spatial data infrastructures and the TPACK model. Education Sciences, 8(171). https://doi.org/10.3390/educsci8040171

2. Ylizandre, N. \& Kiorpes, L. (2018). View from the top (and the bottom) of the World: Teaching climate change from a polar perspective. The Science Teacher, 85(5), 22-30. www.jstor.org/stable/44843585

3. Zangori, L., Peel, A. \& Kinslow, A. (2017). Student development of model-based reasoning about carbon cycling and climate change in a socio-scientific issues unit. Journal of Research in Science Teaching, 54(10), 1249-1273. https://doi.org/10.1002/tea.21404

4. Walshe, N. (2017). An interdisciplinary approach to environmental and sustainability education: Developing geography students' understandings of sustainable development using poetry. Environmental Education Research, 23(8), 1130 1149. https://doi.org/10.1080/13504622.2016.1221887

5. Monroe, M., Hall, S. \& Li, C. (2016). Can climate change enhance biology lessons? A quasi-experiment. Applied Environmental Education and Communication, 15(2), 125-137. https://doi.org/10.1080/1533015X.2016.1164095

6. Raper, D. \& Zander, H. (2009). Paleoecology: An untapped resource for teaching environmental change. International Journal of Environmental and Science Education, 4(4), 441-447. https://files.eric.ed.gov/fulltext/EJ884408.pdf

7. Nolan, E., Whitworth, B. A. \& Rubino-Hare, L. (2019). A lesson in geospatial inquiry. The Science Teacher, 87(4), 26-33. https://doi.org/10.2505/4/tst19 0870426

8. Rudsberg, K. \& Öhman, J. (2015). The role of knowledge in participatory and pluralistic approaches to ESE. Environmental Education Research, 21(7), 955974. https://doi.org/10.1080/13504622.2014.971717 


\section{Ainedidaktiikka 4(3) (2020)}

9. Feierabend, T. \& Eilks, I. (2010). Raising students' perception of the relevance of science teaching and promoting communication and evaluation capabilities using authentic and controversial socio-scientific issues in the framework of climate change. Science Education International, 21(3), 176-196.

https://files.eric.ed.gov/fulltext/EJ904867.pdf

10. Russ, R., Wangen, S. \& Nye, L. (2015). Fields of fuel. Science Teacher, 82(3), 4954. https://doi.org/10.2505/4/tst15 $082 \quad 03 \quad 49$

11. Rule, A. \& Meyer, M. (2009) Teaching urban high school students' global climate change information and graph interpretation skills using evidence from the scientific literature. Journal of Geoscience Education, 57(5), 335-347. https://doi.org/10.5408/1.3559674

12. Gold, A., Oonk, D. \& Smith, L. (2015). Lens on climate change: Making climate meaningful through student-produced videos. Journal of Geography, 114(6), 235246. https://doi.org/10.1080/00221341.2015.1013974

13. Reinfried, S., Aeschbacher, U. \& Rottermann, B. (2012). Improving students' conceptual understanding of the greenhouse effect using theory-based learning materials that promote deep learning. International Research in Geographical and Environmental Education, 21(2), 155-178. https://doi.org/10.1080/10382046.2012.672685

14. Remmen, K. \& Frøyland, M. (2014). Implementation of guidelines for effective fieldwork designs: Exploring learning activities, learning processes, and student engagement in the classroom and the field. International Research in Geographical and Environmental Education, 23(2), 103-125.

https://doi.org/10.1080/10382046.2014.891424

\section{Kirjallisuus}

Aksela, M., Tikkanen, G. \& Kärnä, P. (2012). Mielekäs luonnontieteiden opetus: Miten tukea oppilaiden ajattelua ja ymmärtämistä? Teoksessa P. Kärnä, L. Houtsonen \& T. Tähkä, (toim.), Luonnontieteiden opetuksen kehittämishaasteita (ss. 9-28). Koulutuksen seurantaraportit 2012:10. Helsinki: Opetushallitus.

Anderson, A. (2012). Climate change education for mitigation and adaptation. Journal of Education for Sustainable Development, 6(2), 191-206 https://doi.org/10.1177/0973408212475199

Anderson, L.W., Krathwohl, D.R., Airasian, P.W., Cruickshank, K.A., Mayer, R.E., Pintrich, P.R., Raths, J. \& Wittrock, M.C. (toim.) (2001), A taxonomy for learning, teaching and assessing: A revision of Bloom's taxonomy of educational objectives. Abridged Edition. New York: Addison Wesley Longman.

Boon, H.J. (2010). Climate change? Who knows? A comparison of secondary students and pre-service teachers. Australian Journal of Teacher Education, 35(1), 104 120. https://doi.org/10.14221/ajte.2010v35n1.9

Brundiers, K. \& Wiek, A. (2017). Beyond interpersonal competence: Teaching and learning professional skills in sustainability. Education Sciences, 7, 1-18. https://doi:10.3390/educsci7010039.

Cantell, H. (2004). Johdanto. Teoksessa H. Cantell (toim.), Ympäristökasvatuksen käsikirja (ss. 12-17). Jyväskylä: PS-kustannus.

Cantell, H., Tolppanen, S., Aarnio-Linnavuori, E. \& Lehtonen, A. (2019). Bicycle model on climate change education: Presenting and evaluating a model. Environmental Education Research, 25(5), 717-731. https://doi.org/10.1080/13504622.2019.1570487

Chen, X. (2011). Why do people misunderstand climate change? Heuristics, mental models and ontological assumptions. Climatic Change, 108(1-2), 31-46. https://doi.org/10.1007/s10584-010-0013-5

Choi, S., Niyogi, D., Shepardson, D.P. \& Charusombat, U. (2010). Do earth and environmental science textbooks promote middle and high school students' conceptual development about climate change? Textbooks' consideration of students' misconceptions. Bulletin of the American Meteorological Society, 91(7), 889-898. https://doi.org/10.1175/2009BAMS2625.1

Cooper, J.L., MacGregor, J., Smith, K.A. \& Robinson, P. (2000). Implementing smallgroup instruction: Insights from successful practitioners. New Directions for Teaching and Learning, 81, 63-76. https://doi.org/10.1002/t1.8105 


\section{Ainedidaktiikka 4(3) (2020)}

Gough, D., Oliver, S. \& Thomas. J. (2012). An introduction to systematic reviews. Thousand Oaks, CA: Sage.

Dufty, N. (2018). A new approach to disaster education: The International Emergency Management Society (TIEMS) annual conference, Manila, Philippines, 13-16, November 2018. https://www.academia.edu/37825155/A new approach to disaster_education? email_work_card=view-paper. (Luettu 5.7.2020).

Duschl, R.A. (2008). Science education in three-part harmony: Balancing conceptual, epistemic, and social learning goals. Review Research in Education, 32(1), 268291. https://doi.org/10.3102/0091732X07309371

Eloranta, V., Jeronen, E. \& Palmberg, I. (toim.) (2005). Biologia eläväksi: Biologian didaktiikka (ss. 32-318). Jyväskylä: PS-kustannus.

Grant, R. (1997). A claim for the case method in the teaching of geography. Journal of Geography in Higher Education, 21(2), 171-185. https://doi.org/10.1080/03098269708725423

Haubrich, H. (2007). Geography education for sustainable development. Teoksessa S. Reinfried, S., Schleicher \& A. Rempfler (toim.), Geographical views on education for sustainable development (ss. 27-38). Proceedings. Lucerne-Symposium, Switzerland, July 29-31, 2007. Selbstverlag des Hochschulverbandes für Geographie und ihre Didaktik e.V. (HGD).

Hermans, M. (2015). Niondeklassares och geografilärares förståelse av bakgrunden till och följderna av klimatförändringen. Nordina, 11(1), 54-74. https://doi.org/10.5617/nordina.884

Hicks, D. (2014). Educating for hope in troubled times: Climate change and the transition to a post-carbon future. London: Institute of Education Press.

Holden, J. (toim.) (2012). An introduction to physical geography and the environment. Amsterdam: Pearson.

Hungerford, H. R. \& Volk, T. L. (1990). Changing learner behavior through environmental education. The Journal of Environmental Education, 21(3), 8-21. https://doi.org/10.1080/00958964.1990.10753743

Hyppönen, O. \& Lindén, S. (2009). Opettajan käsikirja - opintojaksojen rakenteet, opetusmenetelmät ja arviointi. Teknillinen korkeakoulu, Opetuksen ja opiskelun tuki. Espoo: HSE Print.

Ilmatieteen laitos (2018a). Kasvihuoneilmiö ja ilmakehän koostumus. Helsinki: Ilmatieteen laitos. https://ilmasto-opas.fi/fi/ilmastonmuutos/ilmio/-/artikkeli/420c4ca3a128-4ae7-882e-3d06e1 ea24f5/kasvihuoneilmio-ja-ilmakehan-koostumus.html. (Luettu 29.4.2019.)

Ilmatieteen laitos (2018b). Ilmastonmuutos ilmiönä. Helsinki: Ilmatieteen laitos. http://ilmasto-opas.fi/fi/ilmastonmuutos/ilmio/-/artikkeli/962d9aa2-e7e3-4df589a2-9f1 f653e0d4e/ilmastonmuutos-ilmiona.html. (Luettu 24.4.2019.)

IPCC (2014). Climate change 2014: Impacts, adaptation, and vulnerability. Working group II contribution to the fifth assessment report of the Intergovernmental Panel on Climate Change. Cambridge: Cambridge University Press.

Jeronen, E. \& Kaikkonen, M. (2002). Thoughts of children and adults about the environment and environmental education. International Research in Geographical and Environmental Education, 11(4), 341-353. https://doi.org/10.1080/10382040208667501

Jeronen, E., Palmberg, I. \& Yli-Panula, E. (2016). Teaching methods in biology education and sustainability education including outdoor education for promoting sustainability: A literature review. Education Sciences, 7(1). https://doi.org/10.3390/educsci7010001

Jokela, T. (1997). Ympäristötaide paikkakasvatuksena. Teoksessa M. Käpylä \& R. Wahlström (toim.), Vihreä ihminen. Ympäristökasvatuksen menetelmäopas, 2 (ss. 149-166). Jyväskylä: Jyväskylän yliopiston täydennyskoulutuskeskuksen oppimateriaaleja, 25.

Kent, M., Gilbertson, D.D. \& Hunt, C.O. (1997). Fieldwork in geography teaching: A critical review of the literature and approaches. Journal of Geography in Higher Education, 21(3), 313-332. https://doi.org/10.1080/03098269708725439

Kern, E. \& Carpenter, J. (1986). Effect of field activities on student learning. Journal of Geological Education, 34(3), 180-183.

Krathwohl, D. (2002). A revision of Bloom's taxonomy. Theory Into Practice, 41(4), 212-218. https://doi.org/10.1207/s15430421tip4104_2 


\section{Ainedidaktiikka 4(3) (2020)}

Käpylä, M. (1995). Ympäristökasvatus koulun oppimis- ja tiedonkäsityksen muuttamisen välineenä. Teoksessa S. Ojanen \& H. Rikkinen (toim.), Opettaja ympäristökasvattajana (ss. 24-39). Helsinki: WSOY.

Kärnä, P., Houtsonen, L. \& Tähkä, T. (toim.) (2012). Luonnontieteiden opetuksen kehittämishaasteita. Koulutuksen seurantaraportit 2012:10. Helsinki: Opetushallitus.

Lambert, J.L. \& Bleicher, R.E. (2013). Climate change in the pre-service teacher's mind. Journal of Science Teacher Education, 24(6), 999-1022. https://doi.org/10.1007/s10972-013-9344-1

Lehtonen, A. \& Cantell, H. (2015). Ilmastokasvatus osaamisen ja vastuullisen kansalaisuuden perustana. Suomen Ilmastopaneeli. Raportti 1/2015. https://www.ilmastopaneeli.fi/wp-content/uploads/2018/10/Ilmastokasvatuksen-raportti-9.6.2015.pdf (Luettu 14.3.2019)

Lehtonen, A., Salonen, A.O. \& Cantell, H. (2019). Climate change education: A new approach for a world of wicked problems. Teoksessa J. Cook (toim.), Sustainability, human well-being, and the future of education (ss. 339-374). Cham: Palgrave Macmillan. https://doi.org/10.1007/978-3-319-78580-6_11

Leiserowitz, A., Smith, N. \& Marlon, J.R. (2011). American teens' knowledge of climate change. New Haven, CT: Yale Project on Climate Change Communication.

https://climatecommunication.yale.edu/wp-content/up-

loads/2016/02/2011_04_American-Teens\%E2\%80\%99-Knowledge-of-ClimateChange.pdf

Lonka, K., Hietajärvi, L., Hohti, R., Nuorteva, M., Rainio, A.-P., Sandström, N., Vaara, L. \& Westling, S.K. (2015). Ilmiölähtöisesti kohti innostavaa oppimista. Teoksessa H. Cantell (toim.) Näin rakennat monialaisia oppimiskokonaisuuksia (ss. 49-76). Jyväskylä: PS-kustannus.

Lotz-Sisitka, H., Wals, A.E.J., Kronlid, D. \& McGarry, D. (2015). Transformative, transgressive social learning: Rethinking higher education pedagogy in times of systemic global dysfunction. Current Opinion in Environmental Sustainability, 16, 73-80. https://doi.org/10.1016/j.cosust.2015.07.018

Macy, J. (1995). Working through environmental despair. Teoksessa T. Roszak, M.E. Gomes \& A.D. Kanner (toim.), Ecopsychology: Restoring the Earth, Healing the Mind (ss. 240-269). San Francisco: Sierra Club.

McMillan, J.H. (2001). Secondary teachers' classroom assessment and grading practices. Educational Measurement Issues and Practice, 20(1), 20-32. https://doi.org/10.1111/j.1745-3992.2001.tb00055.x

McMillan, J.H., Myran, S. \& Workman, D. (2002). Elementary teachers' classroom assessment and grading practices. Journal of Educational Research, 95(4), 203 213. https://doi.org/10.1080/00220670209596593

McNaughton, M.J. (2006). Learning from participants' responses in educational drama in the teaching of education for sustainable development. Research in Drama Education, 11(1), 19-41. https://doi.org/10.1080/13569780500437572

McNaughton, M.J. (2010). Educational drama in education for sustainable development: Ecopedagogy in action. Pedagogy, Culture \& Society, 18(3), 289-308. https://doi.org/10.1080/14681366.2010.505460

Norgaard, K.M. (2011). Living in denial: Climate change, emotions, and everyday life. Cambridge: MIT Press. https://doi.org/10.7551/mitpress/9780262015448.001.0001

Open ilmasto-opas (2019a). Mitä on ilmastokasvatus? Helsinki: Maj ja Tor Nesslingin säätiö. https://openilmasto-opas.fi/ilmastokasvatus/ (Luettu 30.4.2019)

Open ilmasto-opas (2019b). Ilmastonmuutos biologian opetuksessa. Helsinki: Maj ja Tor Nesslingin säätiö.https://openilmasto-opas.fi/biologia/ (Luettu 30.4.2019).

Opetushallitus (2014). Perusopetuksen opetussuunnitelman perusteet 2014. Helsinki: Opetushallitus.

Opetushallitus (2015). Lukion opetussuunnitelman perusteet 2015. Helsinki: Opetushallitus.

Opetushallitus (2019). Lukion opetussuunnitelman perusteet 2019. Helsinki: Opetushallitus.

Oversby, J. (2015). Teachers' learning about climate change education. Procedia - Social and Behavioral Sciences, 167, 23-27. https://doi.org/10.1016/j.sbspro.2014.12.637 


\section{Ainedidaktiikka 4(3) (2020)}

Palmer, J.A. (1998). Environmental education of the 21st century: Theory, practice, progress and promise. London: Routledge. https://doi.org/10.4324/9780203012659

Pihkala, P. (2017). Environmental education after sustainability: Hope in the midst of tragedy. Global Discourse, 7(1), 109-127. https://doi.org/10.1080/23269995.2017.1300412

Pihkala, P. (2019). Climate anxiety. Helsinki: MIELI Mental Health Finland. http://hdl.handle.net/10138/307626

Pruneau, D., Gravel, H., Bourque, W. \& Langis, J. (2003). Experimentation with a socioconstructivist process for climate change education. Journal of Environmental Education Research, 9(4), 429-446. https://doi.org/10.1080/1350462032000126096

Puk, T.G. \& Stibbards, A. (2012). Systemic ecological illiteracy? Shedding light on meaning as an act of thought in higher learning. Environmental Education Research, 18(3), 353-373. https://doi.org/10.1080/13504622.2011.622840

Pyhältö, K., Pietarinen, K. \& Soini, T. (2014). Comprehensive school teachers' professional agency in large-scale educational change. Journal of Educational Change, 15(3), 303-325. https://doi.org/10.1007/s10833-013-9215-8

Ratinen, I. (2013). Primary student-teachers' conceptual understanding of the greenhouse effect: A mixed method study. International Journal of Science Education, 35(6), 929-955. https://doi.org/10.1080/09500693.2011.587845

Ratinen, I. (2016). Primary student teachers' climate change conceptualization and implementation on inquiry-based and communicative science teaching: a design research. (Väitöskirja). Jyväskylän yliopisto. http://urn.fi/URN:ISBN:978-951-39-6667-6

Shepardson, D.P., Niyogi, D., Choi, S. \& Charusombat, U. (2009). Seventh grade students' conceptions of global warming and climate change. Environmental Education Research, 15(5), 549-570. https://doi.org/10.1080/13504620903114592

Shulman, L.S. (1986). Those who understand: Knowledge growth in teaching. Educational Researcher, 15(2), 4-14. https://doi.org/10.3102/0013189X015002004

Silander, P. (2015). Phenomenon based learning. http://www.phenomenaleducation.info/phenomenon-based-learning.html (Katsottu 20.12.2020)

Sterling, S. (2010). Learning for resilience, or the resilient learner? Towards a necessary reconciliation in a paradigm of sustainable education. Environmental Education Research, 16(5-6), 511-528. https://doi.org/10.1080/13504622.2010.505427

Sterman, J.D. (2011). Communicating climate change risks in a skeptical world. Climatic Change, 108(4), 811. https://doi.org/10.1007/s10584-011-0189-3

Stoknes, P. E. (2015). What we think about when we try not to think about global warming: Toward a new psychology of climate action. Vermont: Chelsea Green Publishing.

Taber, F. \& Taylor, N. (2009). Climate of concern: A search for effective strategies for teaching children about global warming. International Journal of Environmental and Science Education, 4(2), 97-116.

Tikkanen, G. (2010). Kemian ylioppilaskokeen tehtävät summatiivisen arvioinnin välineenä. (Väitöskirja). Helsingin yliopisto. http://urn.fi/URN:ISBN:978-952-10-6336-7

Tirri, K., Tolppanen, S., Aksela, M. \& Kuusisto, E. (2012). A cross-cultural study of gifted students' scientific, societal, and moral questions concerning science. Education Research International, Article ID 673645. https://doi.org/10.1155/2012/673645

Tolppanen, S. (2015). Creating a better world: Questions, actions and expectations of international students on sustainable development and its education. (Väitöskirja). Helsingin yliopisto. http://urn.fi/URN:ISBN:978-951-51-1312-2

Tolppanen, S., Aarnio-Linnanvuori, E., Cantell, H. \& Lehtonen, A. (2017). Pirullisen ongelman äärellä: kokonaisvaltaisen ilmastokasvatuksen malli. Kasvatus, 48(5), 456-468.

Tolppanen, S., Claudelin, A. \& Kang, J. (2020). Pre-service teachers' knowledge and perceptions of the impact of mitigative climate actions and their willingness to act. Research in Science Education. https://doi.org/10.1007/s11165-020-09921-1 


\section{Ainedidaktiikka 4(3) (2020)}

Unesco (2017). Education for Sustainable Development Goals: Learning objectives. Education 2030. Paris: Unesco.

https://unesdoc.unesco.org/ark:/48223/pf0000247444 (Luettu 5.9.2019.)

Wakil, K., Rahman, R., Hasan, D., Mahmood, P., \& Jalal, R. (2019). Phenomenon-Based Learning for Teaching ICT Subject through other Subjects in Primary Schools. Journal of Computer and education Research, 7(13), 205-212. https://doi.org/10.18009/jcer.553507

World Meteorological Organization (2018). WMO statement on the state of the global climate 2017. Geneva: World Meteorological Organization. https://library.wmo.int/doc num.php?explnum_id=4453 (Luettu 24.4.2019)

Wolff, L.-A., Sjöblom, P., Hofman-Bergholm, M. \& Palmberg, I. (2017). High performance education fails in sustainability? A reflection on Finnish primary teacher education. Education Sciences, 7, 32. https://doi.org/10.3390/educsci7010032

Yli-Panula, E., Jeronen, E., Lemmetty, P. \& Pauna, A. (2018). Teaching methods in biology promoting biodiversity education. Sustainability, 10, 1-18. https://doi.org/10.3390/su10103812

Yli-Panula, E., Jeronen, E. \& Lemmetty, P. (2020). Teaching and learning methods in geography promoting sustainability. Education Sciences, 10(5). https://doi.org/10.3390/educsci10010005 


\section{Liite 1}

Taulukko 1. Ajattelun tasot luokiteltuna luonnontieteellisestä näkökulmasta suhteessa ilmastonmuutokseen soveltaen Kärnää, Houtsosta ja Tähkää (2012). LOCS (lower order thinking skills), HOCS (higher order thinking skills)

\begin{tabular}{|c|c|}
\hline Päätasot & Alatasot \\
\hline & 1.1 Tunnistaminen \\
\hline 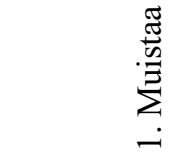 & $\begin{array}{l}\text { 1.2 Mieleen palautta- } \\
\text { minen }\end{array}$ \\
\hline & 2.1 Tulkitseminen \\
\hline & $\begin{array}{l}2.2 \text { Esimerkin antami- } \\
\text { nen }\end{array}$ \\
\hline & 2.3 Luokittelu \\
\hline : : & $\begin{array}{l}\text { 2.4 Yhteenvedon teke- } \\
\text { minen (referointi) }\end{array}$ \\
\hline 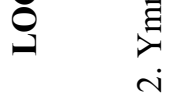 & 2.5 Päättely \\
\hline
\end{tabular}

2.6 Vertaaminen

2.7 Perusteleminen

3.1 Menetelmän toteuttaminen क

3.2 Menetelmän ণ käyttäminen

\section{Esimerkkejä}

Oppilas hakee tietoa muistista, esimerkiksi eniten ympäristöä kuluttavat maat.

Oppilas palauttaa tietoa muistista, esimerkiksi kemialliset symbolit, joita käytetään kasvihuonekaasujen merkinnässä.

Oppilas osaa selittää käsitteen omin sanoin tai muuttaa tietoa, kuten laatia laskun.

Oppilas osaa havainnollistaa käsitteitä tai periaatteita esimerkillä.

Oppilas osaa luokitella asioita kategorioihin.

Oppilas osaa tehdä yhteenvedon muun muassa artikkelista.

Oppilas osaa tehdä loogisia johtopäätöksiä annetun tiedon pohjalta, esimerkiksi jään sulamisen vaikutus alueen eliöstöön.

Oppilas havaitsee kahden asian välillä eroja ja yhtäläisyyksiä.

Oppilas osaa tehdä erilaisista systeemeistä syy-seuraus-malleja.

Oppilas osaa soveltaa rutiininomaista menetelmää tehtävän ratkaisemiseen, kuten kartan lukeminen.

Oppilas osaa käyttää valitsemaansa menetelmää entuudestaan tuntemattoman tehtävän ratkaisemiseen: ongelmanratkaisutehtävät.

Oppilas osaa erotella tehtavänannosta

Oppilas osaa erotella tehtävänannosta olennaiset asiat.

Oppilas tunnistaa tilanteeseen liittyvät perusosat ja osaa muodostaa niistä johdonmukaisia kokonaisuuksia, esimerkiksi tutkimusraportin laatiminen.

Oppilas tunnistaa "rivien välistä luettavat" näkökulmat.

Oppilas osaa tarkistaa, ovatko prosessit johdonmukaisia ja virheettömiä, esimerkiksi tehtävän tai tutkimuksen tuloksen järkevyyden tarkastaminen.

Oppilas osaa arvostella tuotetta ulkoisten kriteerien ja standardien pohjalta, esimerkiksi ilmastonmuutoksen tutkimisessa käytettyjen menetelmien hyvien ja huonojen puolien arvioiminen. 
Ainedidaktiikka 4(3) (2020)

6.1 Kehittäminen Oppilas osaa muodostaa hypoteeseja ja ratkaisutapoja esitettyjen kriteerien pohjalta.

$\begin{array}{ll}\frac{\pi}{0} & 6.2 \text { Suunnitteleminen } \\ \frac{0}{3} & \\ \dot{0} & 6.3 \text { Tuottaminen }\end{array}$

Oppilas osaa suunnitella ratkaisutapoja tehtävän tai ongelman ratkaisuun, esimerkiksi kokeellisen menetelmän suunnitteleminen.

Oppilas osaa tehdä tehtävänannon vaatimusten mukaisen omaperäisen tuotoksen, esimerkiksi esseevastauksen laatiminen.

Taulukko 2. Artikkelien valinnassa käytetyt hakusanat

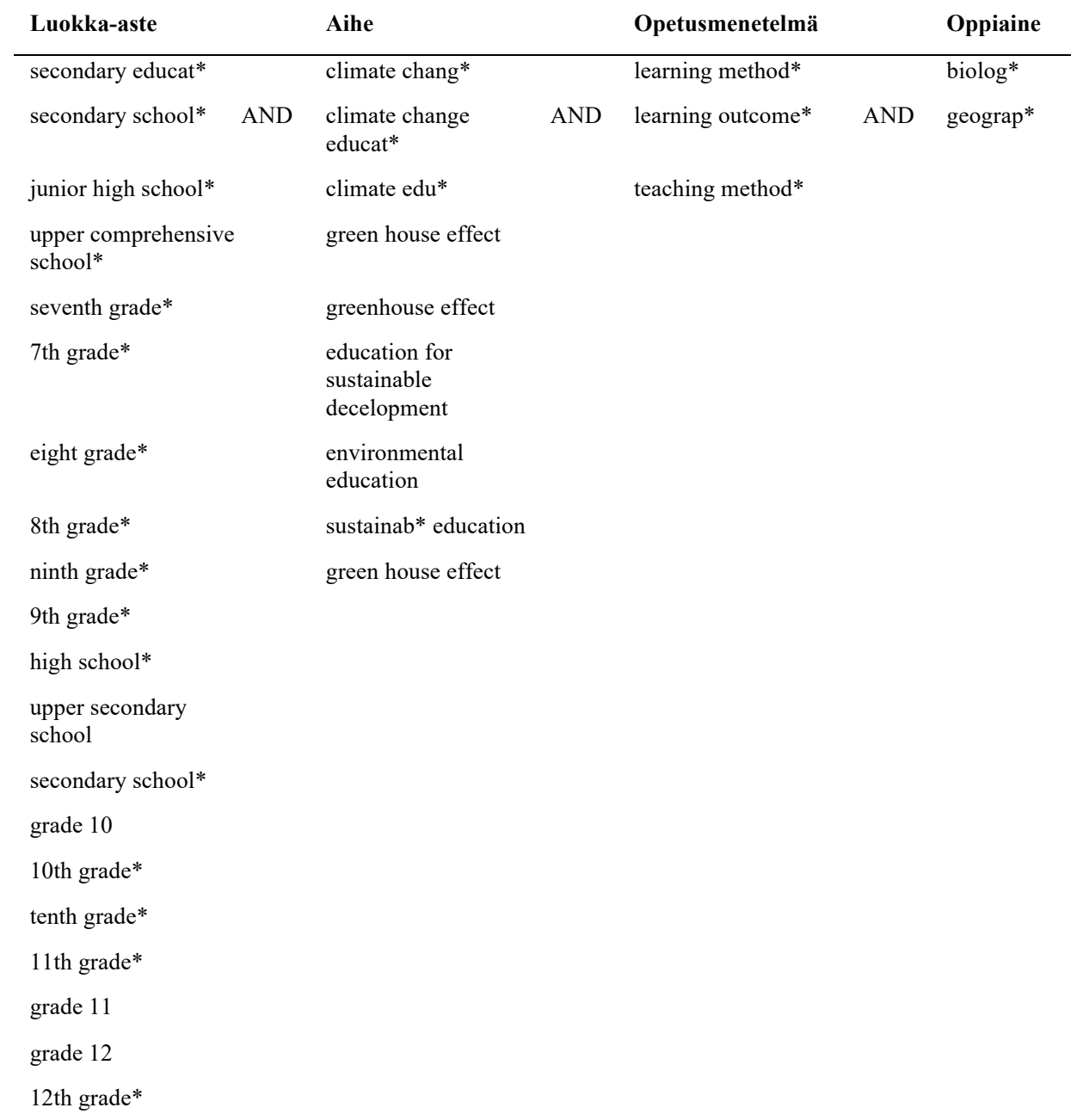

